\title{
AVAILABILITY AND THE USE OF WORK-LIFE BALANCE BENEFITS GUARANTEED BY THE POLISH LABOUR CODE AMONG WORKERS EMPLOYED ON THE BASIS OF EMPLOYMENT CONTRACTS IN SMALL AND MEDIUM ENTERPRISES
}

\section{ALEKSANDRA ANDYSZ, ALEKSANDRA JACUKOWICZ, ALEKSANDER STAŃCZAK, and MARCIN DRABEK}

Nofer Institute of Occupational Medicine, Łódź, Poland

Department of Health and Work Psychology

\begin{abstract}
Objectives: Polish Labour Code provides employees with a range of solutions (benefits) supporting them in achieving balance between work and private life. This paper was aimed at indicating availability and the use of legal benefits supporting work-life balance (WLB) among Polish workers of small and medium enterprises. Material and Methods: The study sample included 219 respondents, aged 22-64, working in small and medium enterprises and employed on the basis of employment contracts for at least a year. The respondents completed a questionnaire on availability and the use of benefits guaranteed by the Polish Labour Code, referring to their current workplaces. Results: Most frequently the studied employees took sick leave because of one's own illness and leave on demand. In our sample, $45 \%$ of the women took maternity leave and $26 \%$ of the men took paternity leave. The respondents took educational and parental leave the least frequently. More than half of the respondents $(58 \%)$ did not return to the same position after leave devoted to childcare, even though they had such a possibility. Conclusions: In fact, most of work-life balance benefits guaranteed by law were available to the employees of small and medium enterprises, regardless of their gender. Availability and the use of the majority of benefits were similar among the women and men. Availability of benefits depended on the specificity of industry and a profession, thus, future research on work-life balance policy should control for variables related to the character of work.
\end{abstract}

Key words:

Gender differences, Small and medium enterprises, WLB benefits, Use of benefits, Availability of benefits, Labour code

\section{INTRODUCTION}

Work-life balance (WLB) reflects distribution of time, energy and engagement between work and family. The balance is a very subjective matter, which depends on many factors, e.g., private situation or the value an individual associates with each sphere. Thus, time, energy and engagement may be distributed unequally between different spheres and still guarantee achievement of WLB [1]. Each person considers different distribution as optimal and this optimum may change with time due to a changing personal or professional situation [2].

Financial support: EOG 78/2013 "EFFECT - Enhancing the effectiveness of work-life balance initiatives use" / Norway Grants in the Polish-Norwegian Research Programme operated by the National Centre for Research and Development. Project manager: Dorota Merecz-Kot, Ph.D.

Received: July 21, 2015. Accepted: September 8, 2015.

Corresponding author: A. Andysz, Nofer Institute of Occupational Medicine, Department of Health and Work Psychology, św. Teresy 8, 91-348 Łódź, Poland (e-mail: andysz@imp.lodz.pl). 
Legislators and employers attempt to respond to employees' need for WLB and they implement various solutions or benefits aimed at facilitating reconciliation between work and private lives (WLB benefits).

Studies on availability and the use of WLB initiatives in Poland are rare, especially when it comes to legal solutions. Previous research has usually provided the percentage of employees using particular benefits, without any information on their practical availability [3]. Other studies lack information both on the availability and methodology [4] or the authors focus only on selected benefits [5]. Thus, in this paper we would like to take a closer look at availability and the use of WLB initiatives among employees of small and medium enterprises. We have chosen this categories of companies as they are usually a step behind in implementing good WLB practices in comparison with big companies.

\section{WLB benefits guaranteed by the Polish Labour Code}

Legal WLB benefits in Poland guaranteed by the Polish Labour Code [6] may be divided into three groups: flexible forms of work, leave and days off, and benefits for working parents.

\section{Flexible forms of work}

There are a few options of flexi-time schedules:

- an employer can introduce a task-based working time system and set the time necessary to complete the assigned task,

- an employee may choose when to start and finish work,

- at the request of an employee, he or she may work a shortened working week by extending the daily working time.

Apart from "flexi-time" there is also a "flexi-place" possibility. An employer may permit employees to work away from the company premises, on a regular basis and with the use of telecommunication ("telework"). Contrarily to the solutions described below, the above ones are only optional and an employer can, but does not necessarily have to, enable employees to use them.

\section{Leave and days off}

The most common option is annual leave, also called "holiday." Each employee has a right to uninterrupted, paid leave, amounting to 20 or 26 days (in the case of job tenure exceeding 10 years). Under such annual leave, in every calendar year an employee is entitled to four days off on demand - these days are usually taken in crisis and an employer should not refuse such a request. There is also paid educational leave -6 days for employees preparing for studies exams, secondary school final exams or professional exams, and 21 days for employees writing and/or defending their thesis. Eventually, at the request of an employee, an employer can grant unpaid leave.

Moreover, the Polish law guarantees financial security for employees unable to work. In the case of an illness or in order to take care of ill family members, they retain the right to sick leave and remuneration equivalent benefit [7]. Finally, in some cases absence at work is legally justified without using leave days: appearance on the demand of authorities, employee's wedding, birth of his or her child, and a funeral of family members [8].

\section{Benefits addressed to working parents}

This group of benefits has changed most over the last few years in Poland [9]. Firstly, six weeks before the expected birth date, a mother can take 20 weeks of maternity leave. Immediately after that, she may also apply for additional maternity leave of up to 6 weeks, which is a novelty. Another novelty is that fathers gained a right to 2 weeks of paternity leave (before a child reaches 1 year). During these 3 types of leave, a parent is entitled to maternity benefit, amounting to $100 \%$ of his or her remuneration. Subsequently, both parents are entitled to parental leave that in total cannot exceed 26 weeks. During this period, an employee gets $60 \%$ of his or her remuneration. However, 
if a mother declares to take maternity leave, additional maternity leave and parental leave, one after another, she is entitled to maternity benefit equal $80 \%$ of remuneration [10]. Working parents can also take unpaid childcare leave for up to 36 months. This leave may be granted only until a child reaches the age of 5 . What is more, a mother has a right to 2 half-hour breaks each day for breastfeeding, and all employees raising a child under 14 are entitled to 2 days off each year to take care of their child. After maternity, paternity or parental leave, employees have a right to return to the same position at work. Moreover, working parents having children aged $<4$ as well as pregnant women may travel in business only on an employer's request and they have a right to refuse.

\section{Aim of the study}

In this paper we addressed the issue of legal WLB benefits availability and use. We assessed the practical availability and use of legally guaranteed solutions for employees of small and medium enterprises (SME) with employment contracts. We chose employees with employment contracts since the benefits we discuss do not apply to the selfemployed and those employed on the basis of civil law contracts.

This is the first, short communication from the project EOG 78/2013 "EFFECT - Enhancing effectiveness of work-life balance initiatives use." In the near future we intend to continue to publish research results of in-depth analyses on availability and the use of WLB benefits as well as their determinants and consequences.

\section{MATERIAL AND METHODS}

\section{Participants}

The sample included 219 respondents (79 men, 140 women) aged 22-64, 53\% of whom worked in small and $47 \%$ in medium enterprises. We used the European Commission's definition of SME based on the number of employees - a small enterprise hires no more than 50 employees and a medium-sized enterprise hires no more than 250 employees. Inclusion criterion was at least one year of job tenure in the current workplace. Each company was represented by up to 10 employees. The respondents completed the questionnaire when at work. The survey was conducted between October and December 2014.

The majority of the study group were women (64\%). Most of the subjects were parents living with children (64\%). The average age of the respondents equaled 43 years (min. - 22, max - 64, standard deviation $(\mathrm{SD})=10.87$ ). There were no significant differences between women and men as regards their age. The average job tenure was 14 years (min. 1 year, $\max 44$ years, $\mathrm{SD}=10.56$ ) and it was significantly longer among the women than among the men $\left(\mathrm{Z}_{(215)}=1.98, \mathrm{p}<0.05\right)$. Comparing to the men, significantly more women had college and higher education. The men were in the majority of respondents with primary and basic vocational education. Significantly more women lived with children aged up to 6 and 7 and more years old. The men prevailed among the respondents living without children. Sample characteristics including other demographic characteristics are presented in Table 1.

\section{Measures}

The respondents completed a self-reported questionnaire developed for the purpose of the study. We asked about gender, age and tenure in the current organization.

The questionnaire consisted of a list of 9 legal WLB solutions guaranteed by the Polish Labour Code, including one item applicable only for women (breastfeeding breaks) (Table 2). The respondents answered the questions about: availability - "In your work, if needed, could you use the following benefits freely?" ("yes"/"no"); the use of a benefit - "Do you use/have you used such a benefit in your current workplace?" ("yes"/"no").

Our analyses were based on the answers referring to the past. Such data are burdened with recall bias. We 
Table 1. Demographic characteristic of the study group

\begin{tabular}{|c|c|c|c|}
\hline \multirow{2}{*}{ Variable } & \multicolumn{3}{|c|}{$\begin{array}{l}\text { Respondents } \\
{[\mathrm{n}(\%)]}\end{array}$} \\
\hline & $\begin{array}{c}\text { women } \\
(\mathrm{N}=140)\end{array}$ & $\begin{array}{c}\text { men } \\
(\mathrm{N}=79)\end{array}$ & $\begin{array}{c}\text { total } \\
(\mathrm{N}=219)\end{array}$ \\
\hline \multicolumn{4}{|c|}{ Family structure $\left(\mathrm{Chi}_{(2,219)}^{2}=9.68, \mathrm{p}<0.01\right)$} \\
\hline living with children aged $0-6$ & $26(19)$ & $12(15)$ & $38(17)$ \\
\hline living with children aged $\geq 7$ & $74(53)$ & $28(35)$ & $102(47)$ \\
\hline living without children & $40(29)$ & $39(49)$ & $79(36)$ \\
\hline \multicolumn{4}{|c|}{ Education $\left(\mathrm{Chi}_{(2,219)}{ }^{2}=28.27, \mathrm{p}<0.001\right)$} \\
\hline primary and basic vocational & $18(13)$ & $35(44)$ & $53(24)$ \\
\hline college & $63(45)$ & $27(34)$ & $90(41)$ \\
\hline higher & $59(42)$ & $17(21)$ & $76(35)$ \\
\hline \multicolumn{4}{|c|}{ Enterprise $\left(\mathrm{Chi}_{(1,219)}^{2}=12.10, \mathrm{p}<0.001\right)$} \\
\hline small-size & $61(44)$ & $54(68)$ & $115(53)$ \\
\hline medium-size & $78(56)$ & $25(32)$ & $103(47)$ \\
\hline
\end{tabular}

Table 2. Availability and the use of work-life balance benefits guaranteed by the Polish Labour Code among workers employed on the basis of employment contracts in small and medium enterprises

\begin{tabular}{|c|c|c|c|c|}
\hline \multirow{3}{*}{ Type of a benefit } & \multicolumn{4}{|c|}{$\begin{array}{l}\text { Benefit } \\
{[\mathrm{n}(\%)]}\end{array}$} \\
\hline & \multicolumn{2}{|c|}{ availability } & \multicolumn{2}{|c|}{ use } \\
\hline & no & yes & yes & no \\
\hline \multicolumn{5}{|l|}{ Applied to all workers } \\
\hline \multicolumn{5}{|l|}{ sick leave because of one's own illness } \\
\hline total $(\mathrm{N}=219)$ & $19(9)$ & $200(91)$ & $143(72)$ & $57(29)$ \\
\hline women $(\mathrm{N}=140)$ & $7(5)$ & $133(95)$ & $92(69)$ & $41(31)$ \\
\hline $\operatorname{men}(\mathrm{N}=79)$ & $12(15)$ & $67(85)$ & $51(76)$ & $16(24)$ \\
\hline \multicolumn{5}{|l|}{ leave on demand } \\
\hline total $(\mathrm{N}=219)$ & $24(11)$ & $195(89)$ & $113(58)$ & $82(42)$ \\
\hline women $(\mathrm{N}=140)$ & $13(9)$ & $127(91)$ & $68(54)$ & $59(46)$ \\
\hline $\operatorname{men}(\mathrm{N}=79)$ & $11(14)$ & $68(86)$ & $45(66)$ & $23(34)$ \\
\hline \multicolumn{5}{|l|}{ paid days off to take care of others } \\
\hline total $(\mathrm{N}=219)$ & $60(27)$ & $159(73)$ & $62(39)$ & $97(61)$ \\
\hline women $(\mathrm{N}=140)$ & $32(23)$ & $108(77)$ & $39(36)$ & $69(64)$ \\
\hline $\operatorname{men}(\mathrm{N}=79)$ & $28(35)$ & $51(65)$ & $23(45)$ & $28(55)$ \\
\hline \multicolumn{5}{|l|}{ educational leave } \\
\hline total $(\mathrm{N}=219)$ & $83(38)$ & $136(62)$ & $43(32)$ & $93(68)$ \\
\hline women $(\mathrm{N}=140)$ & $50(36)$ & $90(64)$ & $26(29)$ & $64(71)$ \\
\hline $\operatorname{men}(\mathrm{N}=79)$ & $33(42)$ & $46(58)$ & $17(37)$ & $29(63)$ \\
\hline
\end{tabular}


Table 2. Availability and the use of work-life balance benefits guaranteed by the Polish Labour Code among workers employed on the basis of employment contracts in small and medium enterprises - cont.

\begin{tabular}{|c|c|c|c|c|}
\hline \multirow{3}{*}{ Type of a benefit } & \multicolumn{4}{|c|}{$\begin{array}{l}\text { Benefit } \\
{[\mathrm{n}(\%)]}\end{array}$} \\
\hline & \multicolumn{2}{|c|}{ availability } & \multicolumn{2}{|c|}{ use } \\
\hline & no & yes & yes & no \\
\hline \multicolumn{5}{|l|}{ Applied to parents only } \\
\hline \multicolumn{5}{|l|}{ maternity/paternity leave } \\
\hline total $(\mathrm{N}=140)$ & $13(9)$ & $127(91)$ & $52(41)$ & $75(59)$ \\
\hline women $(\mathrm{N}=100)$ & $0(0)$ & $100(100)$ & $45(45)$ & $55(55)$ \\
\hline men $(\mathrm{N}=40)$ & $13(33)$ & $27(68)$ & $7(26)$ & $20(74)$ \\
\hline \multicolumn{5}{|c|}{$\begin{array}{l}\text { return to the same work position after maternity, } \\
\text { paternity or parental leave }\end{array}$} \\
\hline total $(\mathrm{N}=140)$ & $21(15)$ & $119(85)$ & $50(42)$ & $69(58)$ \\
\hline women $(\mathrm{N}=100)$ & $10(10)$ & $90(90)$ & $42(47)$ & $48(53)$ \\
\hline $\operatorname{men}(\mathrm{N}=40)$ & $11(28)$ & $29(73)$ & $8(28)$ & $21(72)$ \\
\hline \multicolumn{5}{|l|}{ parental leave } \\
\hline total $(\mathrm{N}=140)$ & $24(17)$ & $116(83)$ & $32(28)$ & $84(72)$ \\
\hline women $(\mathrm{N}=100)$ & $9(9)$ & $91(91)$ & $26(29)$ & $65(71)$ \\
\hline $\operatorname{men}(\mathrm{N}=40)$ & $15(38)$ & $25(63)$ & $6(24)$ & $19(76)$ \\
\hline \multicolumn{5}{|c|}{$\begin{array}{l}\text { reducing the amount of business trips for parents of } \\
\text { children aged up to } 4 \text { years old and pregnant women }\end{array}$} \\
\hline $\operatorname{total}(\mathrm{N}=140)$ & $48(34)$ & $92(66)$ & $25(27)$ & $67(73)$ \\
\hline women $(\mathrm{N}=100)$ & $33(33)$ & $67(67)$ & $18(27)$ & $49(73)$ \\
\hline $\operatorname{men}(\mathrm{N}=40)$ & $15(38)$ & $25(63)$ & $7(28)$ & $18(72)$ \\
\hline \multicolumn{5}{|l|}{ Applied to women only } \\
\hline \multicolumn{5}{|l|}{ breastfeeding break } \\
\hline women $(\mathrm{N}=100)$ & $17(17)$ & $83(83)$ & $18(22)$ & $65(78)$ \\
\hline
\end{tabular}

believe that in contrast to the questions on, e.g., the number of days when an employee was unable to work, days of sick leave or the number of sick leave, life events such as maternity leave, parental leave, taking days off to take care of a sick child are easier to recall. Hence, we consider the recall bias in our study as little. Especially given that we did not inquire how many times the respondents used particular benefits, but about the fact of using them, in general. The only mistake our respondents could make was the fact of using a benefit in the previous, not the current workplace. Yet, we believe such a mistake to be exceptionally rare. Therefore, in our opinion the design of the study did not radically affect the study results and their interpretation.

\section{Analysis}

We calculated the percentages of availability and the use of WLB benefits. Calculations of the use were performed only on the data from the respondents who stated that particular WLB benefits were available for them. Further, for the benefits addressed only to the workers with children (e.g., childcare leave) we excluded childless 
employees. For the analysis of breastfeeding breaks we selected only the women living with children. To assess the differences between the respondents' education and family situation we used the $\mathrm{Chi}^{2}$ test.

Statistical analyses were performed using a statistical package Statistica version 10.

\section{RESULTS}

First, we indicated the respondents who declared to have open access to particular benefits - $63-100 \%$ of employees considered particular legal benefits as available to them. Then, we identified those who made use of particular solutions - 22-72\% of the studied employees used the benefits (Table 2).

\section{DISCUSSION}

Most of WLB benefits guaranteed by law were available to the employees, regardless of their gender. Moreover, availability and the use of the majority of benefits were similar for both - women and men. The women relatively rarely used benefits aimed at facilitating childcare like maternity and parental leave. The use of paternity and parental leave among men was even less frequent.

Sick leave because of one's own illness was the most popular form of WLB benefits addressed to all employees ( $72 \%$ of the respondents who declared such benefits to be available to them used them). This benefit was almost equally commonly used by the women and men $-69 \%$ of the women and $76 \%$ of the men who had access to this benefit, made use of it.

Leave on demand constituted the second most commonly used benefit, both among the men and women. It was used by a half of all the respondents $(58 \%$ of the respondents who declared this benefit to be available to them) and it was more popular among the men than among the women (66\% and 54\%, respectively). These two solutions were available to the vast majority of the respondents.
Yet, despite legal warranty, $9 \%$ of the workers had limited access to sick leave and $11 \%$ to leave on demand. This outcome leaves much room for questions about the reasons of such results. Such a situation may take place in a work environment with an unfriendly organizational culture, which determines particular norms, for example a norm of not taking sick leave [11].

Considering benefits addressed to the working parents, most frequently the respondents used their right to return to the same position after maternity, paternity or parental leave ( $47 \%$ of the women and $28 \%$ of the men who felt they had access to such a benefit). Other working parents either did not return to the same position, even though they had such a possibility (58\%) or claimed they would not have the possibility to return even if there was such a need (15\% of all the studied respondents). Such an opinion was expressed by $10 \%$ of the women and $28 \%$ of the men.

A similar number of employees took maternity and paternity leave - such a solution was more common among the women $(45 \%$ of the women and $26 \%$ of the men who had access to such a benefit declared to have used it).

The data of the Polish Central Statistical Office show that only $5 \%$ of employees (10\% of women and $1 \%$ of men) quit their jobs to take care of their youngest child of their own will [12]. In the case of women, such a result suggests that despite legal warranty, they frequently have no possibility to return to work after leave devoted to take care of a child. In the case of men, it additionally confirms previous research findings showing that men undertaking nonstereotypical roles or social behaviors, like leaving work due to paternal leave, may suffer from serious career consequences. It is probable that men and women are treated differently at work.

Leave addressed to employees taking care of a child and other dependents is mainly addressed to women, as it is commonly believed that these are women who are responsible for taking care of others. In this regard, western 
societies are undergoing changes in the attitudes towards gender roles, which seem more favorable for women their switch from the stereotypical role of a mother and willingness to pursue professional career meets with understanding and approval. This cannot be applied to men who abandon the stereotypical role of economic providers. Men are still less expected to participate in family life and housework. The phenomenon of exceptional negative consequences that men need to face when they make use of their rights as fathers, and decide to engage in family duties more than in work responsibilities, is described as "penalizing men who request family leave" [13]. In work environments rewarding employees for their efficiency and engagement, the men who at some point of their professional careers prefer their parental duties to professional duties are perceived by their benefit-oriented employers as not caring about work and thus, not worth working in that company any longer.

A relatively small group of women who take breaks for breastfeeding may result from the inconvenience connected with making use of this benefit. One hour break for breastfeeding is usually too short to leave work, feed a baby and come back. Also, it is not always possible to have a baby brought to work for breastfeeding. Thus, if this benefit is used, the hour for breastfeeding is taken as the last hour of working time and the women is allowed to finish work an hour earlier. On-site nurseries (on the premises of a company) would be an answer to such a problem, yet, they are still rare in Poland and they are usually available to employees of big companies - therefore, this would not apply to our respondents. Moreover, using this benefit requires interrupting work so it would be only available to women who work on independent positions and perform rather task-based work. Often work procedures and technological processes did not allow for such a break at work. Relatively few employees took maternity/paternity leave $(41 \%)$ and parental leave $(28 \%)$, which reflects economic situation of Polish parents and confirms such leave might be considered a privilege they cannot afford. As previously mentioned, maternity benefits do not always cover $100 \%$ of the salary. Similarly, Polish Central Statistical Office (Główny Urząd Statystyczny - GUS) data reveal that only $20 \%$ of working parents took parental leave, including $1 \%$ of the studied men and $38 \%$ of the studied women [12].

Educational leave was the least popular benefit addressed to all employees, and it was taken only by one in $3 \mathrm{em}$ ployees who had access to this benefit (29\% of the women and $37 \%$ of the men who had the possibility to take it). Although gender differences were rather small, the result confirms previous findings showing that men and women differ as regards the goals they want to achieve by using WLB benefits. Previous research shows that when using benefits, men care more for free time, possibility to pursue their hobbies or to travel, whereas women appreciate the possibility to be available when their families need them [14-16].

It is worth noting again that our study included only SME employees. Limited access to this benefit may result from the specificity of organizations our respondents worked for. Availability of educational leave depends on the type of an industry and profession - it is mostly granted in organizations considering raising qualifications of their employees as their strategic aim. However, such a hypothesis needs a further research verification.

Reducing the number of business trips due to a family situation was the least popular benefit addressed to working parents and there were no gender differences. Probably, low availability and the use of this benefit result from the specificity of our study sample that included no professions in which business trips were essential. Such a benefit might also not be sufficiently promoted among employees and some workers might not know they are entitled to such a benefit. For example, Krawczyk et al. [17] have shown that only $30 \%$ of female and $6 \%$ of male police officers knew their rights concerning WLB benefits. 


\section{Study limitations}

Considering limitations of the study, in this short communication we discussed the issue briefly and with the use of basic statistics allowing only for a crosssectional analysis. One of the major limitations of this study is the fact that we were not able to determine the reasons for small availability of the benefits. We might have observed the extent of the violation of law by the SME employers. Yet, it is also possible that the law, even if well-designed, is not always respected. For example, the specificity of SME might constitute a barrier due to a small number of employees who are irreplaceable, an employee often being a boss at the same time, etc. The studied employees might have also declared that the solutions were not available to them because even though they were guaranteed by law, using them would result in superiors' disapproval, lack of promotion, negative comments, etc. Our data do not allow us to confirm these suppositions.

In this study we referred only to the current workplaces, therefore, small percentage of the use of some benefits might have occurred because some employees used them in previous workplaces. Such shortcoming results from the design of the whole project - aiming to investigate individual and organizational determinants of using WLB benefits, in which we asked about the situation in the current workplace.

Some benefits may have been used that rarely also because it could have been too soon for some employees to use them as they had no family responsibilities or no children. Another limitation of our analysis is the fact that we did not control for age and family situation. In our future research within the ongoing project EOG 78/2013 "EFFECT - Enhancing effectiveness of work-life balance initiatives use" we intend to identify the probable determinants of employees' willingness and preferences in this field controlling for the significant variables.

\section{CONCLUSIONS}

The fact that still quite a large number of SME workers had the feeling that legally guaranteed WLB solutions were not available to them in their workplaces is alarming. This shows the discrepancy between legal order and everyday practice of applying law in Poland, and suggests that employers violate the rights of the contracted workers. The reason of this discrepancy should be carefully studied in the future with special attention paid to the SME sector. Availability of WLB benefits depends on the specificity of companies and a profession. Therefore, future research on WLB policy should control for variables related to the character of work performed by respondents.

A proper assessment of the efficiency of WLB policy requires investigation into the reasons of not using such benefits - whether it is the lack of need for such help or lack of a possibility to use them due to a financial situation, or other reasons. Indicating these determinants would allow accurate correction initiatives.

\section{REFERENCES}

1. Guest DE. Perspectives on the study of work-life balance. Soc Sci Inf. 2002;41(2):255-79, http://dx.doi.org/10.1177/0539018 402041002005

2. Chandra V. Work-life balance: Eastern and western perspectives. Int J Hum Resour Manage. 2012;23(5):1040-56, http:// dx.doi.org/10.1080/09585192.2012.651339.

3. Górska A. [Employees expectations towards facilitating the reconciliation of work and family life (based on the case of Family Assistance Centre in Białystok)]. In: Sadowska-Snarska $\mathrm{C}$, editor. [Reconciliation of work and family life in Poland]. Białystok: Wydawnictwo Wyższej Szkoły Ekonomicznej w Białymstoku; 2013. p. 135-45. Polish.

4. Sadowska-Snarska C. [Supporting work-life balance of employees on the level of companies. Theory and practice]. Res Pap Wroclaw Univ Econ. 2013;292(1):100-18. Polish.

5. Spytek-Bandurska G. [Telework in Poland - Legal and social issues]. Probl Polityki Spol. 2013;21(2):139-53. Polish. 
6. [The Act of 26 June 1974, The Labour Code. J Laws 1974, No. 24, item 141]. Polish.

7. [The Act of 25 June 1999 on social protection through social insurance in case of sickness or maternity. J Laws 1999, No. 60, item 636]. Polish.

8. [The ordinance of the Minister of Labour and Social Policy on 15 May 1996 on the method and procedure of justifying the absence at work and granting employees leaves. J Laws 1996, No. 60, item 281]. Polish.

9. [The Act of 6 December 2008 on the change of Labour Code and other acts. J Laws 2008, No. 237, item 1654]. Polish.

10. [The notice of the Marshall of the Sejm of the Republic of Poland on 22 April 2010 on the announcement of the consolidated law on cash benefits from social insurance in case of illness or maternity. J Laws 2010, No. 77, item 512]. Polish.

11. Kirby E, Krone K. “The policy exists but you can’t really use it": Communication and the structuration of work-family policies. J Appl Commun Res. 2002;30(1):50-77, http:// dx.doi.org/10.1080/00909880216577.

12. Central Statistical Office. [Reconciliation between work and family life in 2010]. Warszawa: The Office; 2012. Polish.
13. Rudman LA, Mescher K. Penalizing men who request a family leave: Is flexibility stigma a femininity stigma? J Soc Issues. 2013;69(2):322-40, http://dx.doi.org/10.1111/ josi.12017.

14. Nabe-Nielsen K, Lund H, Ajslev JZ, Hansen ÅM, Albertsen $\mathrm{K}$, Hvib $\mathrm{H}$, et al. How do employees prioritise when they schedule their own shifts? Ergonomics. 2013;56(8):1216-24, http://dx.doi.org/10.1080/00140139. 2013.815804 .

15. Fujimoto Y, Azmat F, Hartel C. Gender perceptions of work-life balance: Management implications for full-time employees in Australia. Aust J Manage. 2013;38(1):140-71, http://dx.doi.org/10.1177/0312896212449828.

16. Rafnsdóttir GL, Heijstra TM. Balancing work-family life in academia: The power of time. Gender Work Organ. 2013;20(3):283-96,http://dx.doi.org/10.1111/j.1468-0432.2011. 00571.x.

17. Krawczyk W, Modrzejewska A, Parafínski Z. [Educational model of work in the police, concerning the possibility to reconcile family and work life]. Warszawa; Zarząd Wojewódzki NSZZ Policjantów I; 2010. Polish.

This work is available in Open Access model and licensed under a Creative Commons Attribution-NonCommercial 3.0 Poland License - http://creativecommons.org/ licenses/by-nc/3.0/pl/deed.en. 